\title{
'Community Cinema': A Report Based on Material Held at the Rio, Dalston
}

\author{
Guy Barefoot
}

'Two classic films by Eisenstein. October depicts the Russian revolution of 1917. Exhilarating!!!' Such was the Sunday afternoon programme promised in a leaflet advertising the screenings at the Rio, Kingsland High Street, Dalston, in the London Borough of Hackney, for February, 1983. The exhilaration of the afternoon - for audiences who paid the Rio's $£ 2$ admission charge ( $£ 1$ for under $16 \mathrm{~s}$ and UB40s, 50p for pensioners) - was to be found not only in the experience of watching Sergei Eisenstein's 1927 experiment in intellectual montage, but also in the rarer opportunity of viewing Time in the Sun, Marie Seaton's reconstruction of the Russian director's unfinished 1931 film about life and culture in Mexico.

The Rio was at this time operating with significant debts, in a building that was in serious need of repair, while attempting to attract audiences in a borough which that same year had been unkindly described by Paul Harrison as one of two or three contenders for the title of 'The Most Awful Place in Britain' (Harrison 1983: 32). As is well documented, this period was marked by falling cinema attendances across Britain: they had declined from almost 112 million in 1979 to 64 million in 1982 (and would decline further in 1984) (see Hill 1999: 245). The crisis affected cinema exhibitors in general, but there were particular problems for those attempting to operate outside the major chains, and on a basis that was not purely driven by commercial considerations. Whatever the justification for pointing to the potential delights of watching October, those three exclamations marks after 'exhilarating' in the Rio leaflet also could suggest an almost desperate optimism held by those attempting to run a 'community cinema' in such unsympathetic circumstances.

But if the screening of October says something about the enthusiasm of those running the cinema, perhaps the afternoon screening the 
previous Sunday says something about the self-image of the Rio. As the cinema's programme leaflet put it, on 'Sunday 20th February at 2pm the RIO will be holding its annual general meeting in the cinema. The meeting will be preceded by a showing of the Peter Sellers film The Smallest Show on Earth [1957] a comedy about the trials and tribulations of running a local cinema'.

The leaflet is one of a number of documents held by the Rio in the building that still - trials and tribulations notwithstanding - operates as a single-screen cinema under the overall control of an elected Board of Management made up of local volunteers. There are several filling cabinets in the room in which this material is held, filled mostly with film posters accumulated since the 1980s, but also containing other documents collected during this period. There are a number of programme listings, mainly from the 1990s but going back as far as the February 1983 leaflet quoted from above; other leaflets include those promoting the 'Rio Womens Film Programme', and some, issued by unhappy front-of-house workers, calling for people to boycott the cinema's own screening of Blue Velvet (1986). ${ }^{1}$ Further material includes a selection of press clippings relating to the cinema, as well as assorted letters, ranging from complaints about the disappearance of the regular Friday night Martial Arts programme to heartfelt pleas for screenings of Louise Brooks films. Of particular interest, and discussed further below, are several documents addressing the question of the status of the Rio as a 'community cinema'.

This is not an archive available for public access, but an uncatalogued and unsorted collection of material which the cinema has accumulated since it re-opened in February 1979. It is reported on here as an example of the kind of documentation that can be found outside established archives and libraries, and for the particular light it sheds on debates about the possibilities and practicalities of a communitybased cinema.

The material is mainly from the 1990s, though some documents date from the 1980s. An isolated instance from before this period is a photocopy taken from The Ideal Kinema supplement to Kinematograph Weekly (10 February 1938), announcing "A repertory cinema in N. London', and noting that 'the interior is decorated in a modern style with sweeping lines'. In fact, the site where the Rio stands has been used for screening films for close to a hundred years now. It was in 1909 that Claire Ludski converted her shop on Kingsland High Street into the Kingsland Palace, complete with cinema screen and 175 seats. A purpose-built cinema designed by George Coles (the Kingsland Empire, with seating for 956, and 174 standing) was opened on the site 


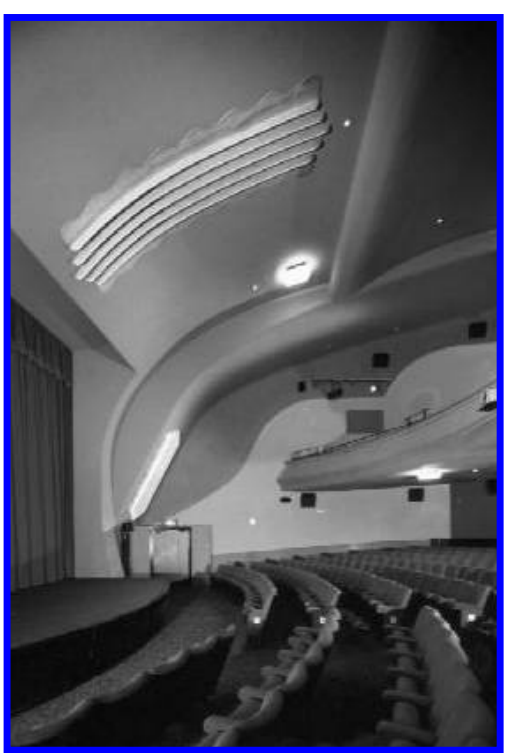

The interior of the Rio: 'A modern style with sweeping lines.'

in 1915. Almost completely rebuilt, to a design by Frederick Bromige, the Kingsland Empire became the Classic in $1937 .{ }^{2}$ It later survived as the Classic Cartoon Cinema, from 1960 as the Classic Continental Cinema, then from 1970 as the Tatler. It briefly became the Dalston Classic again in 1975, closed in 1976, was reopened the same year as the Rio, then closed a further time, before it was revived again, the aim being to establish a 'community centre' devoted, in the words of the articles of association, to 'drama, mime, dance, singing, film, poetry, and music'.

As the Tatler, the cinema had also specialised in double-bills, though these were to be found in the 'Cinema Voyeur' section that listing magazine Time Out then featured, and included programmes such as Sisters in Leather (1969) and Vice Girls Limited (1964), as well as occasional variations such as Trans-Europ-Express (1966, screened with the less-wellknown Aquasex [1962]). While film writers had proposed 'Cinema Voyeur' as a broader category of the cinema-going experience, by 1980 it was being noted in Time Out that over 'the past year the Women's Cinema group have been putting on monthly programmes at the Rio in Dalston. Now, after a lot of research and discussion ... they've put together a well thought out week long programme' (Time Out 1980: $50-1) .{ }^{3}$ The continuation of this trend is testified to in the leaflet, dating from 1985, promoting the 'Rio Womens Film Programme': started in 1984, with the aim of including 'the work of rarely seen early women directors such as Maya Deren, Alice Guy and Lois Weber', a monthly slot 
had, it was noted, provided a space for screenings ranging from The German Sisters (1981)to Clamity Jane [sic] (1953), speakers and discussions, and sessions programmed by women from the Black Audio Film Collective, Irish Women in Hackney and the Women's Media Resource Group.

Of the other material held by the Rio, the press clippings give some insight into the changing fortunes of London repertory and independent cinema over the past fifteen years. A feature from the free weekly events guide $L A M$ from 10 February 1987 noted that 'the Roxie cinema in Wardour Street could be on the verge of closing down [it did] - and other independents may not be far behind'. Here, the Rio was identified as operating 'a strict policy of non-sexist, non-racist films', and concentrating 'on off-beat but popular movies, often with an ethnic flavour'. A wider survey of London cinemas, included in the 23-30 October 1991 issue of Time Out, claimed to cover everything 'from fleapit to picture palace'. The Rio's place was clearly identified in the verdict that this 'very nearly qualifies as a genuine fleapit. It's very run down and untidy but it does deserve some commendation for sticking to inventive independent programming'. On 17 July 1998 the Evening Standard still classified the Rio as London's 'scruffiest but still lovable' cinema, and included a small, accompanying feature headed 'the cinema time forgot'. A more recent Time Out feature on London cinemas (4-11 April 2001) noted the refurbishment that had taken 'the squeak out of its seats and brought a new shine io the architecture', but still described the Rio as 'something of a paradigm of community cinema'.

What constituted 'community cinema' could be unclear or the subject of some debate. In a 1983 article in London's then alternative listing magazine, City Limits, which offered a (largely pessimistic) survey of the state of London's independent cinemas, Rio programmer of the time Rob Rider was quoted as saying: 'We see the Rio as trying to present a type of cinema which is different from the majors, and quite vitally different from the majority of the independents, in that we are trying to explore the whole concept of community cinema. Don't ask me exactly what it is, because our job is discovering it, and working it out' (quoted in McDermott 1983: 18). ${ }^{4}$ Other documents held at the Rio point to attempts at a more precise definition. A discussion paper written by Rio staff, titled 'The Rio - A Model for the Future?' (which I understand was presented to the 1983 AGM) identified six elements which could be taken into account in defining community cinema: 'location in an area of cultural/social deprivation', 'locally managed/ non profit-making', 'based in a cinema building', 'diverse in its activities 


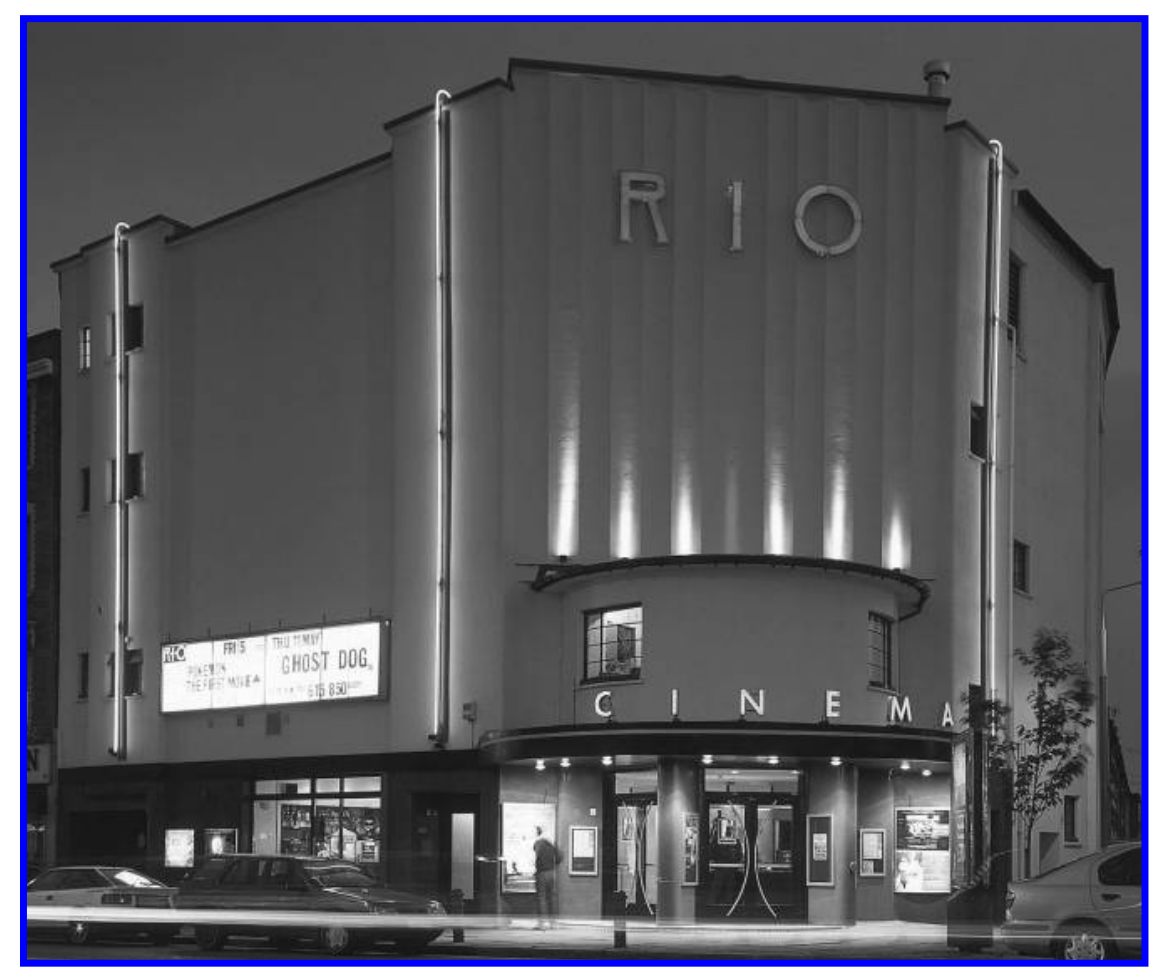

The newly renovated Rio: 'A paradigm of community cinema.'

and media used', 'based on socialist principles', and 'exhibiting noncommercial work'. It was added that there also had to be an 'overall strategy aimed at putting the project to best use with and for the community. Without this, the project is simply independent or noncommercial, without being community based'. Community cinema was proposed here as an alternative to other, 'failed', models offered by the major chains and art-houses (and it was stated that, though the Rio had good relations with the British Film Institute, 'it would never wish to follow the Regional Film Theatre model'). Local control of cultural forms and outlets was seen as 'the most effective way to combat the hijacking of culture and communications by a small, reactionary elite'. ${ }^{5}$

This paper is itself referred to in another document written by Rio staff. The 'front of house proposals for programming policy', dated 20 October 1986, claimed that Rio audiences were failing to reflect Hackney's 'vibrant mixture of various ethnic groupings', attributed this to the nature of the previous two years' programming and the cinema's failure 'to become an ongoing community concern', and argued that 
'The Rio exists on the basis that it is a community cinema, but a redefinition of community cinema is long overdue'. This led to a reconsideration of the elements proposed in 1983, and to questions such as why deprivation should be understood as a prerequisite for a community cinema, and what exactly was meant by 'socialist principles'. Proposals were made in terms of activities and facilities - a crèche, bingo, Sunday afternoons devoted to 'seasons specifically catering for films that would complement students' studies in areas such as "social history" or "film studies" ...' - and partly in terms of the organisation of the cinema, leading to calls for the Rio to "be run along democratic lines', without differences in pay and status.

It is clear that behind this argument about the nature of community cinema was a more specific dispute between different workers at the cinema. Such proposals were made in the context of the continuing financial difficulties experienced by the Rio. But they also point to a broader debate about the nature and viability of different exhibition practices. In the 1980s these debates also occasionally surfaced in journals such as Screen and Framework, as well as at conferences such as 'British Independent Cinema in the '80s' held at Cinema City, Norwich.

In Screen, Steve Neale had noted that 'various and diverse attempts have been and are being made to develop progressive, oppositional practices of film exhibition', and examined the value of different strategies, such as the film season, supporting screenings with documentation, and accompanying films with lectures and discussions (Neale 1980: 45) ${ }^{6}{ }^{6} \mathrm{He}$ also warned of the danger that involving audiences and community groups in programming itself could end up being little more than tokenism (a fear also expressed in the 1983 City Limits piece on independent cinemas, where it was noted that the Rio was 'planning a black film week and a women's film programme in a way in which, the programmers hope, will not be interpreted as tokenism') (McDermott 1983: 18).

In another article, 'The Rio and "Community Cinema", Sean Cubitt, then on the Management Committee, wrote that the "immediate problem with the term is that there is no single community in Hackney; rather a plethora of different, often fragmented and occasionally mutually hostile communities. So the cinema has tried to develop, as far as possible, a policy of working with representative local groups to produce programming, both of films and other events, that will supply the kind of entertainment which otherwise would not reach local people' (Cubitt 1984: 2). For Cubitt the problem, 'of course', was money, though he also identified a need to move beyond a nostalgia for 'the good old days of packed houses and Ealing comedies' (ibid.). This 
emphasis on looking forward can also be found in the discussion paper 'The Rio - A Model for the Future?', which concludes with the assertion that the Rio represents 'a crucial development, and one which should be important to everyone with an interest, direct or indirect, in the future of film and its exhibition'.

Attempting to set up a 'model for the future' could, however, also involve re-investigating the past, whether in terms of unearthing the work of pioneering film-makers, undertaking an oral history of local cinema (one of the potential projects listed in Cubitt's article, though another one accompanied with the proviso that such schemes would require adequate funding), or even screening films, such as The Smallest Show on Earth, that had many of the characteristics of Ealing comedies.

An examination of the Rio's own past suggests that the cinema that emerged in the 1980s may not have been quite the crucial model for the future that some hoped, but as one example of an attempt to construct an alternative approach to running a cinema it represents a significant aspect of film exhibition in Britain. The material that the Rio itself holds can, in conjunction with other sources, help to give an insight into these aspirations and the attempt to realise them. Such material is also relevant to our understanding of the trials and rewards of running a cinema operating outside the majors chains, and of the changing fortunes of such cinemas during this period.

My thanks to Charles Rubinstein, general manager of the Rio.

Notes

1. A leaflet states that the Rio claims to support an anti-sexist policy for employment and film programming, but is showing Blue Velvet 'a film which we consider to be misogyny in the guise of 'Art' ... We are picketing the cinema because we feel that showing this film contravenes the Rio's policy with regard to the representation of women'. Scrawled on the bottom is 'Boycott Blue Velvet! Violence Against women is not Art!' It is believed that one of the screenings of the film at the Rio, was followed by a debate over these issues.

2. For information on Bromige's cinema architecture, see Bruce Peter (2000), 'F.E. Bromige - Cinema Architect', Picture House 25, Autumn, pp. 3-15.

3. The Time Out material referred to in this paragraph is not among the material held at the Rio.

4. This article is not among the material held at the Rio.

5. This paper is identified as a discussion paper reproduced from Film and Video Exhibition and Distribution in London, GLC Economic Policy Group Strategy Document no. 21,1983 .

6. The article was based on a paper delivered at the Cinema City conference. 


\section{Guy Barefoot}

\section{References}

Cubitt, S. (1984), 'The Rio and “Community Cinema”', Framework 24, pp. 2-7.

Evening Standard (1998), 17 July.

Harrison, P. (1983), Inside the Inner City: Life under the Cutting Edge, Harmondsworth: Penguin.

Hill, J. (1999), British Cinema in the 1980s: Issues and Themes, Oxford: Oxford University Press.

Kinematograph Weekly (1938), 'A repertory cinema in N. London', 10 February.

LAM (1987), 10 February.

McDermott, Q. (1983), 'Difficult films for Eady audiences?', City Limits, 18-24 March, p. 18.

Neale, S. (1983), 'Oppositional exhibition - notes and problems', Screen, 21: 3.

Time Out (1980), 9-15 May, pp. 50-1.

Time Out (1991), 23-30 October.

Time Out (2001), 4-11 April.

Guy Barefoot is the author of Gaslight Melodrama: From Victorian London to 1940s Hollywood (Continuum, 2001). He teaches at the University of Leicester and he has been a member of the Board of Management at the Rio since 1994. 